\title{
EFFICACY OF CYCLOCRYOTHERAPY AND TRANSSCLERAL DIODE LASER CYCLOPHOTOCOAGULATION IN THE MANAGEMENT OF REFRACTORY GLAUCOMA
}

\author{
Aleksandar Miljković1,2, Nikola Babić1,2, Vladimir Čanadanovićn ${ }^{1,2}$, \\ Sofija Davidović, ${ }^{1,2}$, Jelena Ljikar ${ }^{2}$ and Marija Vasin ${ }^{1}$ \\ ${ }^{1}$ Faculty of Medicine, University of Novi Sad, Novi Sad, Vojvodina, Serbia; \\ ${ }^{2}$ Eye Department, Clinical Centre of Vojvodina, Novi Sad, Vojvodina, Serbia
}

\begin{abstract}
SUMMARY - Treating advanced glaucoma often requires numerous therapeutic modalities in order to achieve the desired intraocular pressure (IOP) reduction. The purpose of this study was to evaluate the IOP lowering efficacy of both cyclocryotherapy (CCT) and transscleral diode laser cyclophotocoagulation (TS-DCPC) in the management of refractory primary open-angle glaucoma. This prospective, randomized, controlled clinical trial included 40 patients (40 eyes) with refractory glaucoma treated at the Eye Department, Clinical Center of Vojvodina, Novi Sad, Serbia, between January 2016 and June 2019. Twenty patients underwent CCT (group 1), while another twenty patients were treated with TS-DCPC (group 2). Each patient underwent complete eye examination on the treatment day, as well as follow-up eye examinations 7 days and 1,6 and 12 months after the intervention, when IOP and number of anti-glaucoma drugs used were recorded. The median baseline IOP was $36.50 \mathrm{~mm} \mathrm{Hg}$ (IQR, 28.75-42.00) in group 1 and $27.00 \mathrm{~mm} \mathrm{Hg}$ (IQR, 22.00-35.00) in group 2. Follow-up measurements of IOP in group 1 showed the following results: $16.50 \mathrm{~mm} \mathrm{Hg}$ (IQR, 7.7520.00) (60\% decrease from the baseline value), $12.00 \mathrm{~mm} \mathrm{Hg}$ (IQR, 9.25-18.00) (67\% decrease from the baseline value), $9.00 \mathrm{~mm} \mathrm{Hg}$ (IQR, 2.00-13.75) (73\% decrease from the baseline value), and 9.50 (IQR, 2.50-12.00) (75\% decrease from the baseline value) after 7 days, 1, 6 and 12 months, respectively. Follow-up measurements of IOP in group 2 showed the following results: $16.00 \mathrm{~mm} \mathrm{Hg}$ (IQR, 10.00-17.00) (48\% decrease from the baseline value), $14.00 \mathrm{~mm} \mathrm{Hg}$ (IQR, 10.00-16.00) (56\% decrease from the baseline value), $14.00 \mathrm{~mm} \mathrm{Hg}$ (IQR, 12.25-16.50) (43\% decrease from the baseline value) and $14.00 \mathrm{~mm} \mathrm{Hg}$ (IQR, 11.25-15.75) (53\% decrease from the baseline value) after 7 days, 1 , 6 and 12 months, respectively. The mean number of antiglaucoma drugs used decreased from 4 to $0.65 \pm 0.81$ and $2.25 \pm 1.07$ in groups 1 and 2 , respectively. In conclusion, study results confirmed the CCT and TS-DCPC to have a rapid and statistically significant ocular hypotensive effect in eyes with refractory glaucoma at one-year follow-up.
\end{abstract}

Key words: Refractory glaucoma; Cyclocryotherapy; Diode laser cyclophotocoagulation; Intraocular pressure

\section{Introduction}

Treating advanced glaucoma often requires numerous therapeutic modalities in order to achieve the desired effect of intraocular pressure (IOP) reduction. If, after conducting the maximum antiglaucoma medica-
Correspondence to: Aleksandar Miljkovic, $M D, P h D$, Faculty of Medicine, University of Novi Sad, Eye Department, Clinical Center of Vojvodina, Hajduk Veljkova 1, 21000 Novi Sad, Vojvodina, Serbia

E-mail: aleksandar.miljkovic@mf.uns.ac.rs

Received May 8, 2020, accepted July 14, 2020 
tion treatment or surgical procedures, stabilization of IOP in the reference range remains impossible, cyclodestructive procedures are introduced ${ }^{1}$.

Cyclocryotherapy (CCT) is based on rapid tissue freezing to temperatures around $-80{ }^{\circ} \mathrm{C}$, which results in the formation of intracellular microcrystals with consequential damage to the ciliary body epithelium. Moreover, obliteration of small blood vessels and necrosis of the ciliary body contribute to decreased aqueous synthesis. Consequently, reduced aqueous production leads to IOP lowering to an acceptable level ${ }^{2,3}$. However, a possible side effect of this procedure may be damage to the neighboring trabecular meshwork due to extension of the cryoablated area $^{4}$. Therefore, decreased aqueous outflow combined with a good regenerative ability of the ciliary epithelium is the reason for the potential loss of CCT efficacy over time. Another, generally desirable, side effect of CCT is pain relief caused not only by lowering IOP but also due to corneal nerve fiber damage ${ }^{5}$. The overall success rate of CCT in reducing IOP is estimated to be $34 \%-92 \%$, depending on the type of glaucoma ${ }^{6}$, and the desired success is reflected in the improved quality of life of glaucoma patients ${ }^{7}$.

Transscleral diode laser cyclophotocoagulation (TS-DCPC) is a procedure based on the application of laser energy for destruction of ciliary tissue. $\mathrm{Ab}$ sorption of the infrared laser energy $(810 \mathrm{~nm})$ by the ciliary body pigmented epithelium is followed by coagulative necrosis and secretory ciliary apparatus damage with consequential decrease in aqueous produc$t^{2}{ }^{2}$. Some histopathologic studies have shown the strongest coagulative effect to occur in the ciliary body stroma ${ }^{8}$. The clinical effect of all cyclodestructive procedures is mainly achieved by reducing the aqueous humor production. However, although the mechanism itself has not yet been fully clarified, it is indicated that TS-DCPC may also increase ciliary body and scleral permeability via extended extracellular space, thereby enhancing the uveoscleral outflow pathway ${ }^{3,9}$. Some studies have shown that the ciliary body pigmented epithelium absorbs diode laser energy $(810 \mathrm{~nm})$ significantly better than the Nd:Yag laser energy (1064 $\mathrm{nm})$, so it is needed to deliver less energy per spot ${ }^{9}$.

The purpose of this study was to evaluate the IOP lowering efficacy of both CCT and TS-DCPC in eyes with refractory primary open-angle glaucoma.

\section{Patients and Methods}

This prospective, randomized, controlled clinical study included 40 patients (40 eyes) who had unregulated eye pressure despite taking maximal antiglaucoma pharmacotherapy, i.e., patients with refractory glaucoma, treated at the Eye Department, Clinical Center of Vojvodina, Novi Sad, Serbia, between January 2016 and June 2019. The study was conducted in accordance with the Declaration of Helsinki. We received approval from the Ethics Committee of the Eye Department, Clinical Centre of Vojvodina and the Teaching-Scientific Council of the Faculty of Medicine in Novi Sad. A written plan with the informed consent form and patient information was approved by the ethics commissions of the Faculty of Medicine in Novi Sad.

Inclusion criterion was diagnosis of primary openangle glaucoma on maximal antiglaucoma drug therapy with uncontrolled eye pressure. Recruitment of patients was conducted using a computer randomization program. Numbers were assigned to patients who met the inclusion criterion. Then they were randomly allocated to either group by the program and subjected to CCT or TS-DCPC. Group 1 included twenty patients that underwent CCT and group 2 another twenty patients that underwent TS-DCPC.

The values of IOP and number of antiglaucoma drugs used were recorded upon complete eye examination on the treatment day, and then on follow-up examinations taken 7 days and 1, 6 and 12 months after the intervention.

Cyclodestructive treatment was conducted under topical anesthesia (retrobulbar or peribulbar injection of 3-5 mL of either lidocaine hydrochloride alone or in combination with bupivacaine hydrochloride). CCT was performed on a cryotherapy apparatus consisting of an analog control module and a cryoprobe (tip dimension $2.5 \mathrm{~mm}$ ). The anterior edge of the cryoprobe tip frozen to $-60 /-80^{\circ} \mathrm{C}$ was positioned $1.5 \mathrm{~mm}$ behind the surgical limbus. Firm pressure was applied for 60 seconds and the same process was repeated 5-7 times until $180^{\circ}$ were covered. The following diode infrared laser (810 $\mathrm{nm}$ wavelength) parameters were used: power of $2.5 \mathrm{~W}$ and duration of 1.5 seconds. The G-probe contact tip was placed $1.2 \mathrm{~mm}$ behind the surgical limbus and 16-18 spots per session were spread over $270^{\circ}$. The sound of 'pop' or 'snap' at the treatment site was used as the indicator of tissue disruption within the ciliary body. 
In order to prevent potential postoperative inflammatory reactions, topical 1\% dexamethasone every four hours and $1 \%$ atropine sulfate three times a day for the first seven postoperative days were applied in all patients. The antiglaucoma drugs were reduced in frequency or discontinued at the discretion of the clinician during the follow-up period.

Numerical data were presented as minimum, maximum and mean values, standard deviation (SD), median and interquartile range (IQR). Methods of identification of empirical distributions, methods for estimating equality of variance (Levene's test) and methods for estimating significance of difference were used. T test was used for repeated measurements; if assumption of the equality of variance was fulfilled, t-test for independent samples, and if not, then Welch's test was used. Also, Friedman test was used for comparisons within one study group, whereas Mann-Whitney test was used for comparisons between the study groups. Differences were considered significant at $\mathrm{p}<0.05$. Sta-

Table 1. Demographic characteristics of study patients

\begin{tabular}{|l|l|l|l|}
\hline \multicolumn{2}{|l|}{} & $\begin{array}{l}\text { Group 1, } \\
\text { CCT }\end{array}$ & $\begin{array}{l}\text { Group 2, } \\
\text { TS-DCPC }\end{array}$ \\
\hline Number of patients & 20 & 20 \\
\hline Gender & $\begin{array}{l}\text { Male } \\
\text { Female }\end{array}$ & 9 & 9 \\
& 11 & 11 \\
\hline BCVA, n (\%) & $0.05-0.1$ & $8(40 \%)$ & $9(45 \%)$ \\
& L+P+- 0.04 & $5(25 \%)$ & $7(35 \%)$ \\
& L- & $7(35 \%)$ & $4(20 \%)$ \\
\hline $\begin{array}{l}\text { Age, yrs } \\
(\text { mean } \pm S D)\end{array}$ & & $73 \pm 8.87$ & $63.5 \pm 17.42$ \\
\hline
\end{tabular}

$\mathrm{CCT}=$ cyclocryotherapy; TS-DCPC $=$ transscleral diode laser $c y-$ clophotocoagulation; BCVA = best corrected visual acuity tistical analysis was performed using the SPSS version 23.0 software.

\section{Results}

Demographic characteristics of the patients enrolled in the study are presented in Table 1 . The two study groups were homogeneous in the number and gender of subjects. There was a predominance of women in both groups (55\% vs. 45\%). The mean patient age was $73 \pm 8.87$ years in group 1 and $63.5 \pm 17.42$ years in group 2.

The values of IOP measurements prior to the cyclodestructive procedure, and 7 days, 1, 6, and 12 months after the intervention in the two study groups are shown in Table 2.

In group 1, the median IOP values decreased from $36.50 \mathrm{~mm} \mathrm{Hg}$ preoperatively to $16.50 \mathrm{~mm} \mathrm{Hg}, 12.00$ $\mathrm{mm} \mathrm{Hg}, 9.00 \mathrm{~mm} \mathrm{Hg}$ and $9.50 \mathrm{~mm} \mathrm{Hg}$ at 7 days, 1, 6, and 12 months after CCT respectively. In group 2, the median IOP decreased from $27.00 \mathrm{~mm} \mathrm{Hg}$ preoperatively to $16.00 \mathrm{~mm} \mathrm{Hg}, 14.00 \mathrm{~mm} \mathrm{Hg}, 14.00 \mathrm{~mm} \mathrm{Hg}$ and $14.00 \mathrm{~mm} \mathrm{Hg}$ at the same time points after TSDCPC. In both groups, postoperative IOP values were significantly lower compared to the baseline values at each time point ( $<<0.05$; Friedman test). The mean IOP decrease post CCT ranged from $60 \%$ (postoperative day 7) to $75 \%$ (one year after the intervention), whereas after TS-DCPC it ranged from $43 \%$ (6 months postoperatively) to $56 \%$ (one month after the intervention). Graphic presentation of IOP reduction over a one-year monitoring period for both groups is shown in Figure 1.

Wilcoxon rank test was used to determine at which time interval the IOP reduction was statistically significant. In group 1, a statistically significant decrease

Table 2. IOP values in CCT and TS-DCPC groups

\begin{tabular}{|c|c|c|c|c|c|c|}
\hline & \multicolumn{3}{|c|}{ CCT } & \multicolumn{3}{|c|}{ TS-DCPC } \\
\hline $\begin{array}{l}\text { IOP } \\
(\mathrm{mm} \mathrm{Hg})\end{array}$ & Median (IQR) & Reduction \% & Mean (SD) & Median (IQR) & Reduction \% & Mean (SD) \\
\hline Baseline & $36.50(28.75-42.00)$ & & $38.60(12.74)$ & $27.00(22.00-35.00)$ & & $28.25(6.88)$ \\
\hline 7 days & $16.50(7.75-20.00)$ & $60 \%$ & $14.10(7.03)$ & $16.00(10.00-17.00)$ & $48 \%$ & $14.15(4.33)$ \\
\hline 1 month & $12.00(9.25-18.00)$ & $67 \%$ & $12.20(5.89)$ & $14.00(10.00-16.00)$ & $56 \%$ & $13.85(3.60)$ \\
\hline 6 months & $9.00(2.00-13.75)$ & $73 \%$ & $9.10(6.39)$ & $14.00(12.25-16.50)$ & $43 \%$ & $14.50(3.05)$ \\
\hline 12 months & $9.50(2.5-12.00)$ & $75 \%$ & $8.40(5.12)$ & $14.00(11.25-15.75)$ & $53 \%$ & $13.90(2.86)$ \\
\hline
\end{tabular}

$\mathrm{IOP}=$ intraocular pressure; $\mathrm{CCT}=$ cyclocryotherapy; $\mathrm{TS}-\mathrm{DCPC}=$ transscleral diode laser cyclophotocoagulation; $\mathrm{IQR}=$ interquartile range 
of IOP was observed in the first 7 postoperative days and in the period of $1-6$ months $(\mathrm{p}<0.05$; Wilcoxon test). In group 2, the IOP decrease was shown to be statistically significant only immediately after TSDCPC, on postoperative day 7 ( $\mathrm{p}<0.05)$, but there was no further significant decrease in IOP $(p>0.05$; Wilcoxon test).

Comparing the median IOP values between the two groups, it was observed that patients treated with CCT had a significantly higher baseline value (36.5

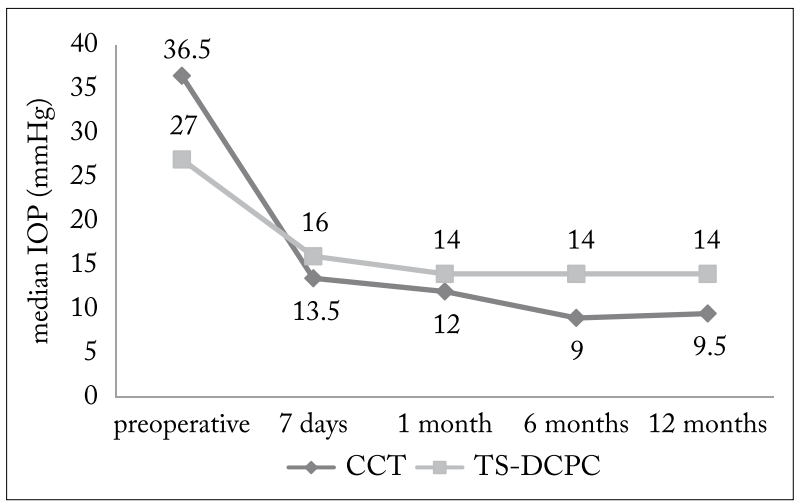

Fig. 1. Median intraocular pressure by treatment groups. $\mathrm{IOP}=$ intraocular pressure; $\mathrm{CCT}=$ cyclocryotherapy; $\mathrm{TS}-\mathrm{DCPC}=$ transscleral diode laser cyclophotocoagulation $\mathrm{mm} \mathrm{Hg}$ vs. $27 \mathrm{~mm} \mathrm{Hg}$ ). Welch t-test was used to compare differences in baseline IOP value and each follow-up IOP value between the groups yielded a statistically significant difference at 6-month follow-up ( $\mathrm{p}=$ 0.002 ) and 12-month follow-up ( $<<0.001)$ (Table 3).

The mean number of antiglaucoma drugs used before the cyclodestructive treatment was similar in both study groups, $3.70 \pm 0.57$ vs. $3.80 \pm 0.41$. One year after the intervention, it was reduced to $0.65 \pm 0.81$ in group 1 and $2.25 \pm 1.07$ in group 2 (Table 4). Comparing these two results, it was shown that the patients treated with CCT used significantly less medication postoperatively compared to the patients treated with diode laser $(\mathrm{p}<0.05$; Mann-Whitney test).

\section{Discussion}

The TS-DCPC and CCT are two widely used cyclodestructive therapeutic modalities for refractory glaucoma. Although there are huge differences in the number of indications for these interventions worldwide (depending on the resources, patient profile, surgeon preferences, etc.), TS-DCPC seems to be a more commonly used method compared to CCT owing to its more focused damage on the ciliary body and less postoperative complications ${ }^{8,10,11}$. However, due to the

Table 3. Welch t-test comparing IOP between the groups during the follow-up period

\begin{tabular}{|l|l|l|l|l|l|}
\hline \multirow{2}{*}{ IOP (mm HG) } & CCT & TS-DCPC & \multicolumn{2}{|l|}{ Welch t-test } \\
\cline { 2 - 6 } & Mean (SD) & Mean (SD) & \multicolumn{2}{|c|}{$\begin{array}{c}\text { Baseline-control } \\
\text { Mean (SD) }\end{array}$} & p value \\
\hline Baseline & $38.60(12.74)$ & $28.25(6.88)$ & - & - & - \\
7 days & $14.10(7.03)$ & $14.15(4.33)$ & $24.50(12.64)$ & $14.10(8.68)$ & 0.979 \\
1 month & $12.20(5.89)$ & $13.85(3.60)$ & $26.40(15.07)$ & $14.40(7.92)$ & 0.292 \\
6 months & $9.10(6.39)$ & $14.50(3.05)$ & $29.50(16.46)$ & $13.75(7.64)$ & 0.002 \\
12 months & $8.40(5.12)$ & $13.90(2.86)$ & $30.20(15.61)$ & $14.35(7.36)$ & $<0.001$ \\
\hline
\end{tabular}

$\mathrm{IOP}=$ intraocular pressure; $\mathrm{CCT}=$ cyclocryotherapy; $\mathrm{TS}-\mathrm{DCPC}=$ transscleral diode laser cyclophotocoagulation

Table 4. Number of drugs used by treatment groups

\begin{tabular}{|l|l|l|l|l|l|}
\hline \multirow{2}{*}{ Number of drugs used } & \multicolumn{2}{|c|}{ CCT } & & \multicolumn{2}{c|}{ TS-DCPC } \\
\cline { 2 - 6 } & Median & Mean (SD) & & Median & Mean (SD) \\
\hline Pretreatment & 4 & $3.70(0.57)$ & $\mathrm{p}=0.768$ & 4 & $3.80(0.41)$ \\
After 12 months & 0 & $0.65(0.81)$ & $\mathrm{p}=0.000$ & 2 & $2.25(1.07)$ \\
\hline
\end{tabular}

$\mathrm{CCT}=$ cyclocryotherapy; TS-DCPC $=$ transscleral diode laser cyclophotocoagulation 
limited number of published studies directly comparing the efficacy in IOP reduction and postoperative complications of the two methods, opinions on which of the two should be the method of choice for refractory glaucoma still differ ${ }^{12}$.

Our study showed a significantly lower post treatment IOP values in both study groups $(\mathrm{p}<0.05)$. We found a reduction in IOP one-year post treatment by $75 \%$ (group 1) and 53\% (group 2) from the baseline values. Such results are completely in accordance with the results of a Korean study (73.9\% reduction of IOP post CCT), as well as with the results of the study by Noureddin et al. (53\% after diode laser treatment) ${ }^{13,14}$. However, Hawkins and Stewart obtained a slightly lower IOP reduction after TS-DCPC (36\%) in their study ${ }^{15}$.

In a multicenter study, 27 patients with refractory glaucoma were followed after TS-DCPC with the following laser parameters: power of $1.5-2 \mathrm{~W}$, duration of $2 \mathrm{~s}$ and $17-19$ laser spots spread over $270^{\circ}$. The IOP dropped from the mean initial pressure level of 36.1 $\mathrm{mm} \mathrm{Hg}$ to $21.6 \mathrm{mmHg}$ and remained essentially unchanged throughout the study ${ }^{16}$. At 6- and 12-month follow-up, our study showed comparable results.

The study by Ataullah et al. conducted in the Manchester Royal Eye Hospital showed IOP decrease by $42 \%$ from baseline six months post diode laser cyclodestruction. In our study, 6 months post TS-DCPC the decrease in IOP was almost identical (43\% from baseline). In both studies, the same laser protocol was applied $^{17}$.

Suresh and Narayan studied the impact of CCT on IOP reduction in patients with absolute glaucoma and showed the success in lowering IOP to increase with time of follow-up. Thus, IOP reduction was $36.1 \%$ at one week of treatment, $68.3 \%$ after 1 month, $73.6 \%$ after 6 months, and $72.7 \%$ after one year ${ }^{18}$. Comparing these values with those recorded in our study, it is concluded that the results are almost identical. The only exceptions are the values recorded after 7 days, when the IOP reduction was significantly higher in our study (60\%). Also, CCT method showed a great overall success in eye pressure reduction in our study, as well as in the study by Krupin et al., where it was $92 \%{ }^{19}$. On the other hand, in the study by Goldenberg-Cohen et al., it was only $60.5 \%$ in the 38 cases analyzed 9

In addition to evaluating the efficacy of IOP reduction of each individual cyclodestructive procedure, we also compared the efficacy of CCT and TS-DCPC. As there was a statistically significant difference in the baseline values of IOP between the groups, by applying an appropriate statistical method, Welch t-test, we were able to compare these two groups. In this way, we minimized the known fact that high initial IOP values affect a higher percentage reduction of IOP after cyclodestructive procedures ${ }^{3}$. IOP reduction in the CCT group was statistically significantly higher than in the TS-DCPC group at 6 and 12 months. Tzamalis et al. also compared these two cyclodestructive methods. They recorded similar but slightly lower IOP reductions after one year, i.e. $54.1 \%$ and $45.5 \%$ post CCT and TS-DCPC, respectively ${ }^{12}$. The time to reach maximum IOP reduction differed between the study groups. In the CCT group, the greatest decrease in eye pressure was observed after one year (75\%), while in the TS-DCPC group the greatest IOP decrease was achieved already after 1 month (53\%). The efficacy of diode laser in maintaining low IOP values can be lost over time, and it is often necessary to repeat the intervention ${ }^{20}$. A possible explanation for additional IOP decrease during the follow-up in the CCT group lies in the treatment protocol, which was not adapted to each individual patient, thus several patients having very low single-digit IOP values at the end of the study. Also, an additional possibility of excluding topical antiglaucoma therapy in the CCT group could be used in a larger number of patients.

It must also be taken into consideration that the TS-DCPC group patients were younger than the CCT group patients. Patient age affects final result of treatment not only in cyclodestructive procedures, but also in the entire glaucoma surgery. It is known that the IOP lowering effect disappears faster in younger than in older patients, which may have an impact on the perception of our results ${ }^{3}$.

The results of this and other studies suggest that CCT and TS-DCPC are the methods that rapidly and effectively lower $\mathrm{IOP}^{9,10,19}$. However, as the goal in treating refractory glaucoma is to maintain IOP as low as possible, most patients continued with antiglaucoma pharmacotherapy post-treatment. In both study groups, the mean number of antiglaucoma drugs used before the cyclodestructive treatment was 4 . After the cyclodestructive surgery, it was reduced to $0.65 \pm 0.81$ and $2.25 \pm 1.07$ in the two groups, respectively. These results are comparable with the results reported by the Korean scientists (number of antiglaucoma drugs reduced to $0.4 \pm 0.5$ one year after CCT) and American scientists (number of antiglaucoma drugs reduced to 
2.0 one year after TS-DCPC) ${ }^{13,21}$. It was also observed that patients treated with cryo method used significantly fewer drugs postoperatively compared to patients treated with diode laser $(\mathrm{p}<0.05)$. This once more confirmed CCT as a more potent method ${ }^{19}$.

\section{Conclusion}

This study confirmed that both CCT and TSDCPC have a rapid and statistically significant ocular hypotensive effect in eyes with refractory open-angle glaucoma at one-year follow-up. Moreover, this study confirmed CCT to be a more potent method compared with TS-DCPC because of more intense IOP reduction achieved and less antiglaucoma medication requirements after the intervention. For good outcome of the refractory glaucoma treatment and in order to keep the target IOP after cyclodestruction as low as possible, it is necessary to continue with a corrected number of antiglaucoma drugs and to conduct eye examinations regularly. Considering the results of this study, we believe that cyclodestructive procedures should be used more often and earlier in treating patients with refractory, especially open-angle glaucoma.

\section{References}

1. European Glaucoma Society. European Glaucoma Society Guidelines (2014): Terminology and Guidelines for Glaucoma. $4^{\text {th }}$ edn. Savona, Italy: Editrice DOGMA, 2014; p. 79-89.

2. Lee WR. Absolute Glaucoma. Ophthalmic Histopathology. London: Springer, 2002; p. 63-99.

3. Dastiridou AI, Katsanos A, Denis P, Francis BA, Mikropoulos $\mathrm{DG}$, Teus MA, et al. Cyclodestructive procedures in glaucoma: a review of current and emerging options. Adv Ther. 2018; 35(12):2103-27. DOI: $10.1007 / s 12325-018-0837-3$

4. Prost M. Anatomy of the ciliary body and cyclocryotherapy. Ophthalmologica. 1984;188:9-13. DOI: 10.1159/000309338

5. Benson MT, Nelson ME. Cyclocryotherapy: a review of cases over a 10-year period. Br J Ophthalmol. 1990;74:103-5. DOI: 10.1136/bjo.74.2.103

6. Shakeel S. Transscleral diode laser cyclophotocoagulations. In: Eric DR, Alanna SN, Richard JN, eds. Operative Dictations in Ophthalmology. Springer International Publishing, 2017; p. 161-8.

7. Runjić T, Novak Lauš K, Vatavuk Z. Effect of different visual impairment levels on the quality of life in glaucoma patients. Acta Clin Croat. 2018 Jun;57(2):243-50. DOI: 10.1136/ bjo.2005.072777

8. Lin SC, Chen MJ, Lin MS, Howes E, Stamper RL. Vascular effects on ciliary tissue from endoscopic versus trans-scleral cy- clophotocoagulation. Br J Ophthalmol. 2006;90(4):496-500. DOI: $10.1136 /$ bjo.2005.072777

9. Goldenberg-Cohen N, Bahar I, Ostashinski M, Lusky M, Weinberger D, Gaton DD. Cyclocryotherapy versus transscleral diode laser cyclophotocoagulation for uncontrolled intraocular pressure. Ophthalmic Surg Lasers Imaging. 2005 JulAug;36(4):272-9.

10. Gorsler I, Thieme H, Meltendorf C. Cyclophotocoagulation and cyclocryocoagulation as primary surgical procedures for open-angle glaucoma. Graefes Arch Clin Exp Ophthalmol. 2015 Dec;253(12):2273-7. DOI: 10.1007/s00417-015-3159-z

11. Kramp K, Vick H, Guthoff R. Transscleral diode laser contact cyclophotocoagulation in the treatment of different glaucomas, also as primary surgery. Graefes Arch Clin Exp Ophthalmol 2002;240:698-703. DOI: 10.1007/s00417-002-0508-5

12. Tzamalis A, Pham DT, Wirbelauer C. Diode laser cyclophotocoagulation versus cyclocryotherapy in the treatment of refractory glaucoma. Eur J Ophthalmol. 2011;21(5):589-96. DOI: 10.5301/EJO.2011.6326

13. Kim BS, Kim YJ, Seo SW, Yoo JM, Kim SJ. Long-term results from cyclocryotherapy applied to the 3o'clock and 9o'clock positions in blind refractory glaucoma patients. Korean J Ophthalmol. 2015;29(1):47. DOI: 10.3341/kjo.2015.29.1.47

14. Noureddin BN, Zein W, Haddad C, Ma'luf R, Bashshur Z. Diode laser transscleral cyclophotocoagulation for refractory glaucoma: a 1 year follow-up of patients treated using an aggressive protocol. Eye (Lond). 2006;20(3):329-35. DOI: 10.1038/sj.eye. 6701875

15. Hawkins TA, Stewart WC. One-year results of semiconductor transscleral cyclophotocoagulation in patients with glaucoma. Arch Ophthalmol. 1993;111(4):488-91. DOI: 10.1001/archopht.1993.01090040080035

16. Kosoko O, Gaasterland DE, Pollack IP, Enger CL. Long-term outcome of initial ciliary ablation with contact diode laser transscleral cyclophotocoagulation for severe glaucoma. The Diode Laser Ciliary Ablation Study Group. Ophthalmology. 1996; 103(8):1294-302. DOI: 10.1016/s0161-6420(96)30508-3

17. Ataullah S, Biswas S, Artes PH, O’Donoghue E, Ridgway AE, Spencer AF. Long term results of diode laser cycloablation in complex glaucoma using the Zeiss Visulas II system. Br J Ophthalmol. 2002;86(1):39-42. DOI: 10.1136/bjo.86.1.39

18. Suresh KS, Narayan M. Cyclo-cryotherapy for the management of absolute glaucoma in rural areas. Indian J Clin Exp Ophthalmol. 2016;2(1):48-51.

19. Krupin T, Mitchell KB, Becker B. Cyclo-cryotherapy in neovascular glaucoma. Am J Ophthalmol. 1978;86:24-6. DOI: 10.1016/0002-9394(78)90008-9

20. Iliev ME, Gerber S. Long-term outcome of trans-scleral diode laser cyclophotocoagulation in refractory glaucoma. Br J Ophthalmol. 2007;91(12):1631-5. DOI: 10.1136/bjo.2007.116533

21. Beardsley R, Law SK, Caprioli J, Coleman AL, Nouri-Mahdavi $\mathrm{K}$, Hubschman J-P, et al. Comparison of outcomes between endoscopic and transscleral cyclophotocoagulation. Vision. 2017;1(4):24. DOI: 10.3390/vision1040024 


\section{Sažetak \\ UČINKOVITOST CIKLO-KRIOTERAPIJE I TRANS-SKLERALNE DIODA LASER CIKLO-FOTOKOAGULACIJE U LIJEČENJU REFRAKTORNOG GLAUKOMA}

\section{A. Miljković, N. Babic, V. Čanadanović, S. Davidović, J. Ljikar i M. Vasin}

Liječenje uznapredovalog glaukoma zahtijeva brojne terapijske modalitete kako bi se postiglo željeno sniženje intraokularnog tlaka (intraocular pressure, IOP). Cilj ove studije bio je utvrditi učinkovitost ciklo-krioterapije i dioda laser ciklo-fotokoagulacije u sniženju IOP-a kod bolesnika s refraktornim glaukomom. Ova prospektivna, randomizirana klinička studija obuhvatila je 40 bolesnika (40 očiju) s refraktornim glaukomom liječenih na Univerzitetskoj klinici za očne bolesti Kliničkog centra Vojvodine, Novi Sad, Srbija, u razdoblju od siječnja 2016. do lipnja 2019. godine. Kod 20 bolesnika primijenjena je ciklo-krioterapija (1. skupina), dok je drugih 20 bolesnika liječeno trans-skleralnom dioda laser ciklo-fotokoagulacijom (2. skupina). Kod svakog bolesnika napravljen je kompletan oftalmološki pregled neposredno prije tretmana, potom 7. dana te 1,6 i 12 mjeseci nakon intervencije, kada su zabilježene vrijednosti IOP-a i broj primijenjenih antiglaukomskih lijekova. Srednji IOP prije intervencije iznosio je $36,50 \mathrm{~mm} \mathrm{Hg}$ (interquartile range (IQR), 28,75-42,00 mm Hg) u 1. skupini i 27,00 $\mathrm{mm} \mathrm{Hg}$ (IQR, 22,00-35,00 mm Hg) u 2. skupini. Tijekom razdoblja praćenja srednje vrijednosti IOP-a u 1. skupini bile su: $16,50 \mathrm{~mm} \mathrm{Hg}$ (IQR, 7,75-20,00) (60\% sniženja), 12,00 mm Hg (IQR, 9,25-18,00) (67\% sniženja), 9,00 mm Hg (IQR, 2,00-13,75) (73\% sniženja) i 9,50 (IQR, 2,50-12,00) (75\% sniženja) nakon 7 dana, 1, 6 i 12 mjeseci. Tijekom razdoblja praćenja srednje vrijednosti IOP-a u 2. skupini bile su: 16,00 mm Hg (IQR, 10,00-17,00) (48\% sniženja), 14,00 mm Hg (IQR, 10,00-16,00) (56\% sniženja), 14,00 mm Hg (IQR, 12,25-16,50) (43\% sniženja) i 14,00 mm Hg (IQR, 11,25-15,75) (53\% sniženja) nakon 7 dana, 1, 6 i 12 mjeseci. Prosječan broj antiglaukomskih lijekova smanjen je s početnih 4 na $0,65 \pm 0,81$ u 1. skupini, odnosno 2,25 $\pm 1,07$ u 2. skupini. Ova studija potvrdila je da su ciklo-krioterapija i trans-skleralna dioda laser ciklo-fotokoagulacija visoko učinkovite ciklodestruktivne metode koje dovode do brzog i statistički značajnog sniženja IOP-a kod bolesnika s refraktornim glaukomom tijekom jednogodišnjeg praćenja.

Ključne riječi: Refraktorni glaukom; Ciklo-krioterapija; Dioda laser ciklo-fotokoagulacija; Intraokularni tlak 